\title{
The Impact of Perceived Internal Corporate Social Responsibility on Organizational Citizenship Behavior: A Micro-Perspective Analysis
}

\author{
Iffat Rasool ${ }^{1}$, Ansir Rajput ${ }^{2}$
}

\begin{abstract}
In the last few years, the trend of research on corporate social responsibility (CSR) has increased, but the question of how employees perceive internal CSR is ignored. The extent of CSR literature has mainly focused on macro concepts rather than micro concepts. The objective of this study was to investigate the impact of internal corporate social responsibility on employees' behavior through their attitude as micro analysis. Therefore, the present study has explored the indirect mechanism of perceived internal corporate social responsibility and organizational citizenship behavior through sequential mediation of perceived organizational support and organizational trust that helps in attaining the desired organizational goals as organizational citizenship behavior.
\end{abstract}

Keywords: Perceived internal CSR, trust, perceived organizational support, Organizational citizenship behavior

\section{Introduction}

Recently, concern has increased on establishing a strategy for organizations' corporate social responsibility in order to achieve a high level of competitive advantage (Doda, 2015). Almost 93\% of leading organizations formally report on CSR (KPMG, 2013). The literature on corporate social responsibility suggests embedding corporate social responsibility in the organizational core strategy (Prutina \& Sehic, 2016) because the organizations with corporate social responsibility in their strategy are more attractive to talented and committed employees (Brammer, Millington, \& Rayton, 2007). However, despite the compliance on the strategic importance of corporate social responsibility for organizational performance (Servaes \& Tamayo, 2013), work place (Abd-Elmotaleb, Saha, \& Hamoudahb, 2015), and involvement in the strategy

1 PhD Scholar, Capital University of Science and Technology, Islamabad. Email: iffatrasool23@gmail. com

2 Associate Professor, Capital University of Science and Technology, Islamabad. Email: dr.ansir. rajput@gmail.com

\begin{tabular}{lll} 
ARTICLE HISTORY & & \\
27 Nov, 2016 Submission Received & 18 Dec, 2016 & First Review \\
\hline 28 Dec, 2016 Revised Version Received & 15 Jan, 2017 & Second Review \\
\hline 1 Feb, 2017 Revised Version Received & 15 Feb, 2017 & Accepted
\end{tabular}


of every major organization, the research on corporate social responsibility related to employees remains deficient (Glavas, 2016; Kolk, Vock, \& Dolen, 2015). According to the literature reviewed by Glavas and Kelly (2014) on corporate social responsibility more than half of the peer-reviewed articles have been published during the last decade, but the employees as stakeholders are ignored.

Observing the importance of internal corporate social responsibility, a number of studies (Glavas, 2016; Sheel \& Vohra, 2016; Newman, Nielsen, \& Miao, 2015; Glavas \& Kelly 2014; De Roeck, Marique, Stinglhamber, \& Swaen, 2014) have attempted to explore the micro CSR in relation to internal corporate social responsibility and investigated how the corporate social responsibility affects employee attitudes and behaviors (Rupp \& Mallory, 2015). Similarly, the study of Abd-Elmotaleb et al. (2015) suggests that employee relations with internal CSR are the strongest among other relations of employee and CSR segments. However, most of these studies ignore the exact nature of the relationship of employees' perceptions of internal CSR. Therefore, the present study has investigated these gaps. First, there is a lack of deep investigations of internal corporate social responsibility as empirical and confirmatory studies (Mory, Wirtz, \& Gottel, 2016). Second, internal corporate social responsibility is less explored through social exchange for employees' behaviors. Third, the mechanism for how employee perception of internal corporate social responsibility affects their behavior is also a neglected area of research (Glavas \& Kelly, 2014). Fourth, the observed literature has also revealed that by and large, research on corporate social responsibility has been conducted in the western perspective (Jones Willness, \& Madey, 2014). Fifth, the investigation of internal corporate social responsibility in developing countries has not been explored fully (Abd-Elmotaleb et al., 2015); therefore, the study of Rupp, Shao, Thornton, and Skarlicki. (2013) advocated for contextualizing corporate social responsibility in other regions.

Due to these outlined gaps in research, the objective of the present study is twofold: first, to develop the mechanism that examines the relationship between perceived internal CSR and employee behavior; second, to uncover the impact of perceived internal CSR on behavior through several intervening attitudes of social exchange. Internal CSR can be defined as an ethical behavior of an organization toward employees because the behavior of an organization can be better perceived through internal marketing and the practices of internal corporate social responsibility (Mory et al., 2016). Thus, the authors have linked the perceived internal corporate social responsibility with attitudes and behaviors under social exchange in the lens of the explored literature of Newman et al. (2015), Shen and Benson (2014), and Agunis and Glavas (2012) by contributing a theoretical model with two intervening constructs:(1) the perceived organizational support (2) trust in relations to perceived internal CSR 
and organizational citizenship behavior in Pakistan in the telecom industry, which can help developing the level of perception of management researchers, academicians, policy makers, and the managers who are interested in the improvement of employee-related issues. Further, the perceived model answers the question, "What motivates employees to go into an extra role as OCB?" The relation of two intervening variables-perceived organizational support and trust as attitude-are used to suggest the relationship of employees' motivations for $\mathrm{OCB}$ as a social exchange process. The social exchange theory suggests that several transactions and exchanges are staged on organizational platforms. Most of the previous research has overlooked the construct of trust in social exchange and focused on only perceived organizational support and ignored the role of trust; whereas trust is the outcome of perceived organizational support (Wong et al., 2012). However, perceived organizational support emerges from internal CSR practices (Rhoades \& Eisenberger, 2002a).

\section{Literature Review}

Corporate social responsibility is a diverse and emerging concept (Hansen, Dunford, Boss, Boss, \& Angermeier, 2012). There is no universal agreement on the definition of CSR (Dahlsrud, 2008). The literature proves that the earliest classical concept of CSR is limited to only philanthropic activities; later, its definition spreads to other areas as well. Overall, CSR is a multidisciplinary approach beyond the legal standards and complies with a moral obligation of market and nonmarket stakeholders at large (Ismail, 2011). In general, CSR has two considerations: (1) the "business case", or the ethical behavior of firms, (2) the role of government while framing the agenda for CSR through legislation (Ward \& Smith, 2015). Further, Green paper of the European Commission (2001) has classified corporate social responsibility as external and internal CSR. Internal CSR deals with the physiological and psychological working environment of internal stakeholders- especially employees-while external CSR is associated with external stakeholders such as NGOs' community, environment, etc. (Ferreira \& Real de Oliveira, 2014)

\subsection{Perceived Internal CSR}

Perception is an individual's psychological drive that leads to the development of one's behavior (Shin, Hur, \& Kang, 2016). However, perception linked to internal corporate social responsibility is cognition for practices and polices related to the physiological and psychological wellbeing of employees (Hameed, Riaz, Arain, \& Farooq, 2016; Azim, M. T., Diyab, \& Al-Sabaan,, 2014). These practices have significant roles in employee behavior at work (Cable \& Judge, 1996). Perception as a cognitive process of individuals is unique among employees. These differences can have an effect on employees' behavior through their attitudes (Rupp, Ganapathi, Aguilera, \& Williams, 
2006). Perceived internal CSR has been viewed in the literature of corporate social responsibility through several viewpoints such as organizational citizenship behavior (Newman, Nielsen, \& Miao, 2015), commitment (Hofman \& Newman, 2014), and identification (Kim, Lee, Lee, \& Kim, 2010). However, employee perception of corporate social responsibility has not been investigated adequately (Parker et al., 2003). According to Aguilera, Rupp, Williams, and Ganapathi, (2007), an organization's social practices signal the employees to evaluate the behavior of the organization toward employees. Therefore, employees' perceptions about organizational action may lead to a change in employees' attitudes and behaviors (Aguilera, et al., 2007) and as a result, the management can reap long-term advantages (Prutina \& Sehic, 2016). Employee perceptions of CSR have great importance in their attachment to the organization (Lee, Song, Lee, Lee, \& Bernhard 2013). Employee perception in a work environment has been observed in several studies (Glavas \& Kelly, 2014; Shin et al., 2016; Prutina \& Sehic, 2016).

\subsection{Perceived Organizational Support}

Perceived organizational support is the outcome of organizational activities toward employees. Employees evaluate the perceived organizational support against the care of organization shown for employees. A formal concept of perceived organizational support was not determined until 1980 (Beheshtifar \& Herat, 2013) and formally it is discussed by Eisenberger, Huntington, Hutchinson, \& Sowa (1986) as perception of employees' about their wellbeing. The management with strong authority for managing activities has a stronger impact of perceived organizational support than a weaker one (Eisenberger, Aselage, Sucharski, \& Jones, 2004). Perceived organizational support is observed with several commitment variables in the study of Kim, Esienberger, and Baik (2016), with commitment and retention in Vardaman et al. (2016), and as a moderator with person-organization fit and organizational citizenship behavior in Chung, (2015). The level of organizational support can be better judged with the concept of employee perception (Wayne, Shore, \& Liden, 1997), while organizational support through the care they receive from the organization. The employees who find high levels of perceived organizational support reciprocate through positive behavior, which helps the organizations meet their goals and achieve set targets (Eisenberger et al., 1986). The employees with greater perceived organizational support are more satisfied (Rhoadas \& Eisenberger, 2002), regular, efficient, and are less likely to quit their jobs (Allen, Peltokorpi, \& Rubenstein, 2016) and go beyond their duties.

\subsection{Trust}

Trust (among employees and trust in an organization as a whole is considered to be similar to trust in interpersonal relationships. Organizational trust has been 
studied in sociology, psychology, and management (Yildiz \& Öncer, 2012) and has a great significance in organizational behavior. Trust, however, has no common definition. Normally it is considered as an honest and trustworthy behavior (Güçer, \& Demirdağ, 2014), and expected moral confidence in someone. Organizational trust as component of trust is an assessment how the employees perceive the organization as trustworthy (Rusu \& Babos, 2015). An employee who has trust in an organization performs confidently and displays organizational citizenship behavior.

Organizational trust impacts organizational performance. If the organization practices its policies with justice, the employees receive a message of trust. Organizational trust also helps in developing the psychological state which provides a feedback of employees' perception about endangering situations that the organization may face (Vanhala, Heilmann, \& Salminen, 2016). Brown, Gray, McHardy, and Taylor (2015) explored the relationship of employee trust at workplace and found a positive correlation. The relationship of corporate social responsibility and trust is found positively significant in the study of Lee et al. (2013). The study of Goergen, Chahine, Brewster, and Wood (2013) studied trust with firm performance and found a positive relation between them. Ethical leadership and organizational trust are also observed in the study of Xu, Loi, and Ngo (2016).

\subsection{Organizational Citizenship Behavior}

Organizational citizenship behavior is a discretionary behavior and is not concerned with a formal job description. This is an expectation of responsible and extra role behavior of employee such as helping a new co-worker or an individual with a heavy workload, voluntary participation in office meetings, paying attention to self-development to become resourceful, and not complaining about minor problems (Podsakoff, Whiting, Podsakoff, \& Blume, 2009). Katz (1964) regarded the organizational citizenship behavior as "innovative and spontaneous behaviors," that are not a part of the job description for organizational performance. Organ (1988) defined it as individual behavior that is discretionary, not directly or explicitly recognized by the formal reward system, and that in the aggregate promotes the effective functioning of the organization. Many of the researchers relate social exchange theory to organizational citizenship behavior, as it is a reverse behavior.

\section{Theoretical Framework}

The significance of internal CSR is inevitable for the organizational performance. The efficiency of employees is based upon the treatment they receive by the management of the organization. Based on social exchange theory, the perceived organizational support and trust reciprocates the positive outcome behavior. Howev- 
er, if the reciprocate process of the social exchange process is not fulfilled then these factors may elicit differences and stress. However, Cropanzano, and Mitchell (2005) suggest that reciprocity varies among the individuals and those who have high levels of reciprocity return high levels of performance and positive behaviors. Therefore, following the social exchange theory, we propose a model as shown in Figure 1 to answer the calls discussed as study gaps.

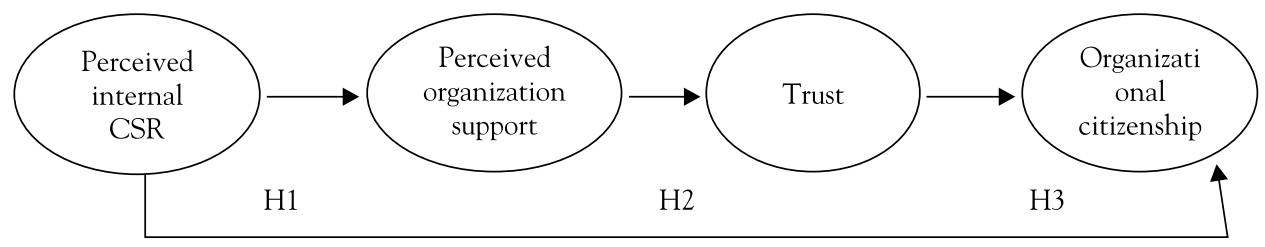

$\mathrm{H} 4$

Figure 1. Theoretical Perceived Model

Like external CSR, the internal CSR has its own importance. According to Turker (2009), the internal CSR is linked with a physiologically and psychologically endowed working environment. Today, employees are more interested to understand the role of internal CSR for their own welfare and interest instead of for society and external stakeholders (Abd -Elmotalib, et al., 2015). Internal CSR is found closely related to employees in research due to its equity based practices for internal stakeholders like equal opportunity for employees, diversity at the workplace, health and safety, etc. (Gond, El-Akremi, Igalens, \& Swaen, 2010). The social exchange theory describes that individuals reciprocate based on what they receive, and employee perception of internal CSR declares about how much an employer cares about the employee. Perceived organizational support is a key antecedent of employee attitude in the social exchange theory and receives the direct effect of internal CSR in the studies of Glavas and Kelly (2014). Therefore:

$\mathrm{H}_{1}$ : Perceived internal CSR positively influences the perceived organizational support.

The level of perceived organizational support can be better evaluated with a mean of employee perception (Wayne et al., 1997). It shows the quality of the relations between employees and the organization (Konijnenburg, 2010) and develops the employee behavior (Ali, Rehman, Yilmaz, Nazir, \& Ali, 2010). The employees identify the perceived organizational support through the respect and care they receive from the organization (Krishhan \& Mary, 2012). Perceived organizational support is a measuring tool on the micro level of employee attitudes toward employers and observes how much the employee perceives about their authorities (Shore \&Wayne, 1993). Perceived organizational support is an element of Blau's (1964) social exchange theory where the 
recipients of perceived organizational support are obliged with its positive attitude and return a positive attitude to the organization as trust. When the organization supports and cares the employees beyond its legal obligations, it obliges the employees to return against the provided care as trust. Both perceived organizational support and trust are the components of social exchange where the trust is the result of favorable exchange. When employees feel that they are being treated ethically they start developing their trust in organization (Wech, 2002). According to Shoss, Eisenberger, Restubog, and Zagenczyk, (2013), the lower the perceived organizational support, the lower the trust of employee on organization. The results of study of Simsarian Webber, Bishop, and O'Neill (2012) find that perceived organizational support significantly and positively relates to the trust of employees in an organization.

$\mathrm{H}_{2}$ : Perceived organizational support positively influences organizational trust.

Trust in an organization is the innate faith of employees that an organization will not trespass their interests (Robinson, 1996). Trust is a basic factor that generates the organizational citizenship behavior. Organizational citizenship is a discretionary behavior and gets developed according to an individual's own perception and trust. The study of Altuntas and Bylcal (2010) found the relation of trust and organizational citizenship behavior, and stated that employees who trust their organization show high levels of citizenship behavior. The study of Yildiz and Öncer (2012) also found the positive relation between trust and organizational citizenship behavior. Therefore:

$\mathrm{H}_{3}$ : Trust positively influences organizational citizenship behavior.

A wide variety of literature supports the importance and influence of corporate social responsibility on employees' attitudes and behaviors toward the organization. The perceived internal corporate social responsibility serves as a signal to employees about their care and respect. The ethical culture of a work environment boosts the positive behavior of employees (Valentine \& Barnett, 2003). Internal CSR satisfies the psychological needs of employees within the organization (Aguilera et al., 2007). Employees' perception of an organization as supportive, ethical, just, and fair may have a positive effect on their behavior. When employees find that their organization involved in ethical behavior, they also start feeling positively, which most likely results as an increased organizational citizenship behavior (Hansen, 2011). Internal CSR is getting attention from diverse research backgrounds as well (Ismail, 2011). Therefore:

$\mathrm{H}_{4}$ : Perceived internal corporate social responsibility positively influences the organizational citizenship behavior.

The employee receiving perceived organizational support feels honored, acknowledged, and protected (Malhotra \& Singh, 2015) therefore organization need to take 
supportive action for employees. The positive actions of an organization as internal CSR may develop trust for organization (Eisenberg et al., 1986) and as a result, employees respond positively (Rhoades \& Eisenberger, 2002). Similarly, the studies of Driks and Ferrin, (2002) and Wong, Wong, and Ngo, (2012) support the positive relation of perceived organizational support and organizational trust. Several studies have found that trust in an organization positively related to organizational citizenship behavior (Aryee, Budhwar, \& Chen, 2002) and mediated between perceived organizational support and organizational citizenship behavior (Singh and Sirvatasa, 2016). Further, the results in the study of Chen, Eisenberger, Johnson, Sucharski, and Aselage, (2009) show trust as a mediator between perceived organizational support and organizational citizenship behavior. Thus:

$\mathrm{H}_{5}$ : Perceived organizational support and trust sequentially mediate the relationship of perceived internal corporate social responsibility and organizational citizenship behavior.

\section{Methodology}

Since the objective of the research was to examine the impact of perceived internal CSR on organizational citizenship behavior, the employees of the telecom industry were selected as a respondent because it is one of the industries heavily involved in CSR practices in Pakistan (Ali et al., 2010). The sample of 1,013 employees was used. The data was collected through a cross-sectional survey. The questionnaire method was approached for the survey. The great advantage of using a questionnaire tool is that it has the capacity of measuring the perceptions, reactions, and attitudes of the targeted sample (Johnson \& Christenson, 2004). The data was collected from multiple ages, education levels from different cities nationwide as shown in Table 1.

\subsection{Measures}

To measure the independent variable, perceived internal CSR, six items were adopted from the Turker (2009) study. Mediating variables, the perceived organizational support was based on eight items from the Eisenberger et al. (1986) study and trust was based on six items from the Podskoff, MacKenzie, Morrman, and Fetter, (1990) study. The dependent variable OCB was measured against nine items from Smith, Organ, and Near, (1983). The questionnaire was designed in two parts. The first part was demographic details of participants and the second part was the fivepoint Likert scale from (1 = "Strongly Agree" to 5 = "Strongly Disagree") to measure the data of variables. 
Table 1: Demographics

\begin{tabular}{|c|c|c|c|c|c|c|c|}
\hline $\begin{array}{c}\text { Demo- } \\
\text { graphic } \\
\text { Variables }\end{array}$ & Codes & $\begin{array}{l}\text { Frequen- } \\
\text { cy }\end{array}$ & $\begin{array}{l}\text { \% Total } \\
\text { Sample }\end{array}$ & Mean & S.D & Skewness & Kurtosis \\
\hline \multirow{2}{*}{ Gender } & Male & 692 & 68.2 & \multirow{2}{*}{1.32} & \multirow{2}{*}{.47} & \multirow{2}{*}{.72} & \multirow{2}{*}{-1.39} \\
\hline & Female & 323 & 31.2 & & & & \\
\hline \multirow{5}{*}{$\begin{array}{l}\text { Age (In } \\
\text { years) }\end{array}$} & Below 20 & 38 & 3.7 & \multirow{5}{*}{2.7} & \multirow{5}{*}{.85} & \multirow{5}{*}{.36} & \multirow{5}{*}{. .13} \\
\hline & $21-25$ & 374 & 36.8 & & & & \\
\hline & $26-30$ & 414 & 40.8 & & & & \\
\hline & $31-35$ & 161 & 15.9 & & & & \\
\hline & $36-40$ & 48 & 2.8 & & & & \\
\hline \multirow{4}{*}{$\begin{array}{c}\text { Education } \\
\text { (in years) }\end{array}$} & Below 14 & 43 & 4.2 & \multirow{4}{*}{2.3} & \multirow{4}{*}{.61} & \multirow{4}{*}{.49} & \multirow{4}{*}{.20} \\
\hline & 14 & 612 & 60.0 & & & & \\
\hline & 16 & 326 & 32.1 & & & & \\
\hline & Above 16 & 34 & 3.3 & & & & \\
\hline \multirow{5}{*}{$\begin{array}{l}\text { Experi- } \\
\text { ence (in } \\
\text { years) }\end{array}$} & Below 5 & 239 & 23.5 & \multirow{5}{*}{2.0} & \multirow{5}{*}{.78} & \multirow{5}{*}{.25} & \multirow{5}{*}{.29} \\
\hline & $5-10$ & 471 & 46.4 & & & & \\
\hline & $10-15$ & 279 & 27.5 & & & & \\
\hline & $15-20$ & 23 & 2.3 & & & & \\
\hline & Above20 & 3 & .3 & & & & \\
\hline
\end{tabular}

\subsection{Confirmatory Factor Analysis}

The study used Structural Equation Modeling for measuring the good fit of the model and data analysis that underwent several phases. Confirmatory factor analysis was used to exclude the low factor loaded items. The elimination of low factor loading items was based on Nunnally and Bernstein (1994). This study has four latent variables (i.e. PICSR, POS, TRUST, and OCB). Four items of perceived internal CSR, four items of POS, three items of trust, and four items of OCB were finalized after deleting the factor loading items. The correlations, means, and standard deviations of all continuous variables in the study have been presented in Table 2 . All the variables correlate with each other significantly.

\subsection{Model fit for Measurement Model}

Before moving to measurement model fit, the study validates the convergent and discriminate validity analysis. According to Hair, Black, Babin, and Anderson, (2010), factor loading, average variance extracted, and composite reliability are the 
Table 2: Descriptive and Correlation Analysis

\begin{tabular}{|c|c|c|c|c|c|c|}
\hline & Means & SDs & PICSR & POS & TRUST & OCB \\
\hline PICSR & 2.2 & .59 & 1 & & & \\
\hline POS & 2.0 & .66 & $0.42^{* *}$ & 1 & & \\
\hline TRUST & 2.1 & .67 & $0.23^{* *}$ & $0.43^{* *}$ & 1 & \\
\hline OCB & 2.1 & .72 & $0.55^{* *}$ & $0.40^{* *}$ & $0.51^{* *}$ & 1 \\
\hline
\end{tabular}

Correlation is significant at the 0.01 level (2-tailed) PICSR $=$ Perceived internal corporate social responsibility, $\mathrm{POS}=$ Perceived organizational support, $\mathrm{OCB}=$ Organizational citizenship behavior

key factors to approach the convergent validity of constructs. Table 3 shows that composite reliability (CR) ranges from 0.8 to 0.9 , which is exceeding 0.7 the required range suggested by Fornell and Larcker (1981). However, average variance extracted (AVE) ranges from 0.5 to 0.6 , which is acceptable at a minimum of 0.5 (Fornell \& Larcker, 1981).

Table 3: Convergent and Discriminate Validity Analysis

\begin{tabular}{|c|c|c|c|c|c|c|}
\hline S.N & Latent Variables & $\begin{array}{c}\text { Retained items of } \\
\text { latent variable }\end{array}$ & $\begin{array}{c}\text { SMC } \\
\text { Range }\end{array}$ & $\begin{array}{c}\text { St. Factor } \\
\text { Loading }\end{array}$ & CR & AVE \\
\hline 1 & $\begin{array}{c}\text { PICSR (with 4 } \\
\text { items) }\end{array}$ & C1, C2, C3, C4 & $.54-.83$ & $.30-.68$ & 0.8 & 0.5 \\
\hline 2 & POS (with 4 items) & P2, P5, P6, P7 & $.62-.76$ & $.39-.58$ & 0.8 & 0.5 \\
\hline 3 & $\begin{array}{c}\text { TRUST (with 3 } \\
\text { items) }\end{array}$ & T1, T2, T3 & $.54-.89$ & $.29-.80$ & 0.8 & 0.6 \\
\hline 4 & $\begin{array}{c}\text { OCB (with 4 } \\
\text { items) }\end{array}$ & $\begin{array}{c}\text { OC1, OC2, OC4, } \\
\text { OC5 }\end{array}$ & $.72-.99$ & $.52-.98$ & 0.9 & 0.6 \\
\hline
\end{tabular}

PICSR= Perceived internal corporate social responsibility, $\mathrm{POS}=$ Perceived organizational support, $\mathrm{OCB}=$ Organizational citizenship behavior, TRUST= Organizational trust

Next, model fit for measurement was estimated and results were satisfactory and all four indices values showed acceptable fitness (i.e. CMIN/DF= 3.0, GFI= 0.96, AGFI $=0.95, \mathrm{NFI}=0.97, \mathrm{CFI}=0.98$, and RMSEA $=0.04)$. Thompson (2000) suggests two elements in SEM, namely CFI and RMSEA, as indicators of best model fit

\subsection{Testing Hypothesized Model through Structural Modeling}

\subsubsection{Direct effects}

The relationship of paths between independent and dependent variables of the hypothesized model was analyzed on SEM. The acceptability of the hypothesis is based 


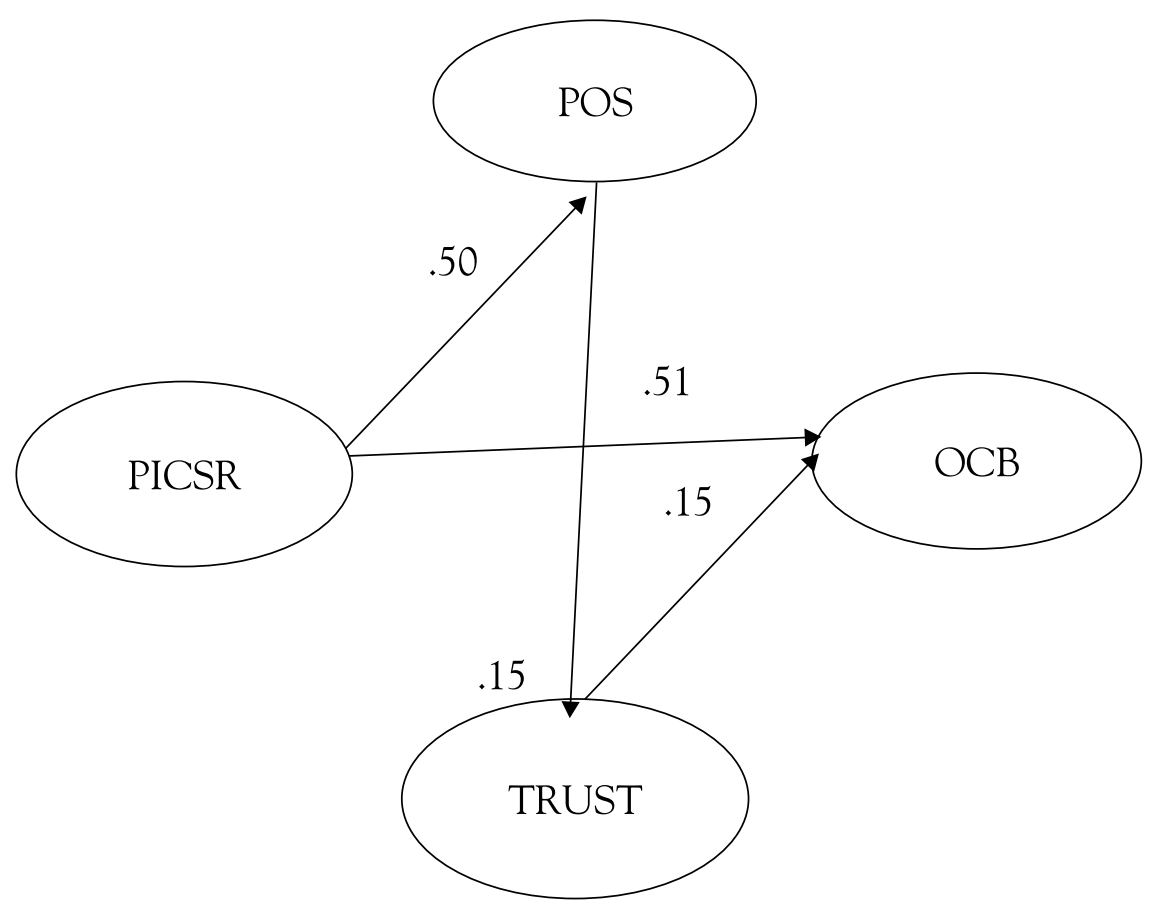

Figure 2: Results of Structural Model

on P value that should be less than .05 (Shaffer, 1995). The study tested the direct effect of four variables as a path analysis from PICSR to OCB and found significant positive effects. The standard regression weight obtained in the results shows the direct effects of variables in the path in Figure 2 shown below.

The hypothesized structural model produced a very good fit with the data CMIN/ $\mathrm{df}=3.8, \mathrm{GFI}=0.95, \mathrm{NFI}=0.95$, and CFI $=0.97$, $\mathrm{RMSEA}=0.05$. The result did not suggest any subtraction of paths. Thus, the hypothesis H.1.H.2, H.3, and H.4 were accepted as shown in Figure 2.

\subsubsection{Mediation effects}

Mediation helps in explaining why and how an independent variable impacts the outcome dependent variable. This study has used the structural equation modeling framework for mediation analysis, as it is more suitable inference framework for mediation analysis of attitudes and behavior types (Gunzler, Chen, Wu, \& Zhang, 2013). Therefore, following other studies (e.g. Iacobucci, Saldanha, \& Deng, 2007), we checked the mediation through SEM. Mediation analysis was made on AMOS with bootstrapping of 5000 with $95 \%$ biased corrected percentile method based on methodology recommended by Meeker and Escobar (1998). The results in Table 4 show the significant relation among the variables defined. 


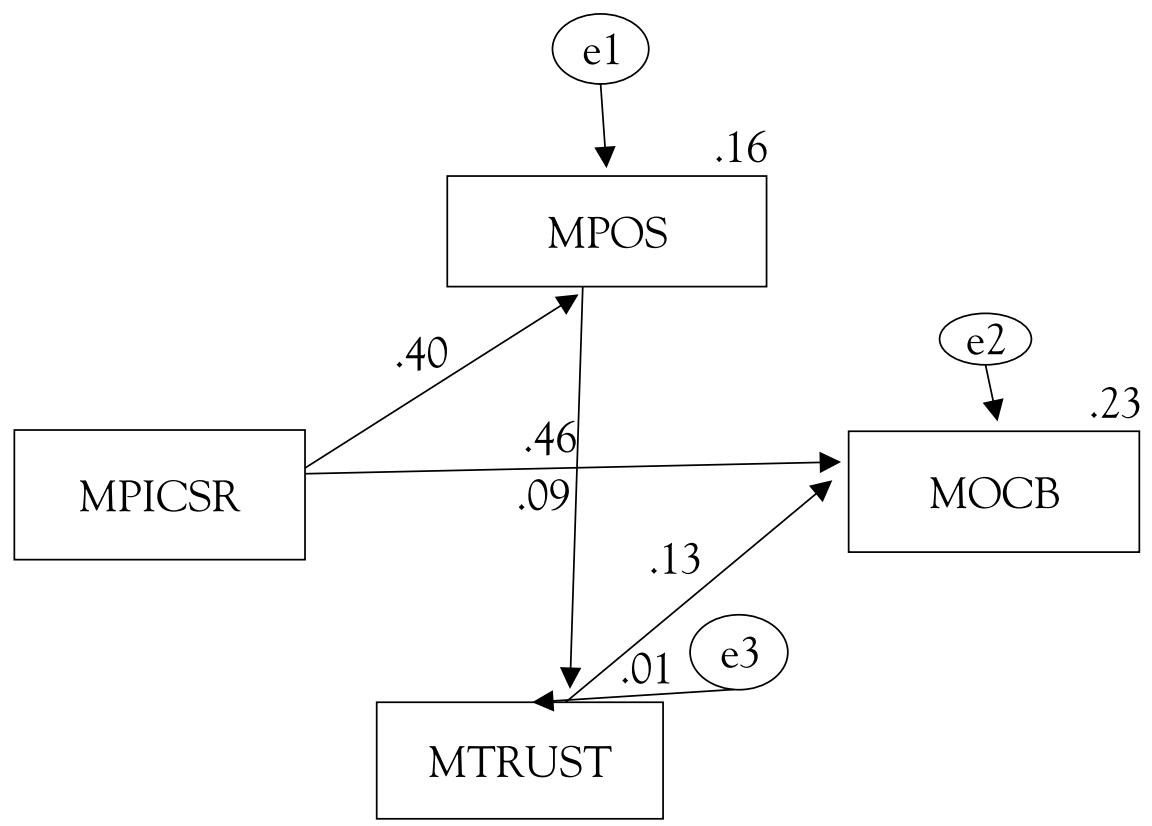

Figure 3: Mediation Model

Table 4. Regression Weights

\begin{tabular}{|c|c|c|c|}
\hline Variables & Estimate & S.E. & P Values \\
\hline MPOS $<-$ MPICSR & .40 & .032 & $* * *$ \\
\hline MTRUST $<-$ MPOS & .09 & .031 & .005 \\
\hline MOCB $<-$ MPICSR & .56 & .034 & $* * *$ \\
\hline MOCB $<-$ MTRUST & .13 & .030 & $* * *$ \\
\hline
\end{tabular}

MPICSR $=$ Mean of perceived internal corporate social responsibility, MPOS= Mean of perceived organizational support, $\mathrm{MOCB}=$ Mean of organizational citizenship behavior, MTRUST $=$ Mean of organizational trust

All the direct and indirect relations are found significant $(\mathrm{P}<.01)$ and both POS and trust partially mediate the relationship between perceived internal CSR and OCB, and total effect is below than $<0.05$ as shown in Table 5 .

Table 5: Total Effect

\begin{tabular}{|c|c|c|c|}
\hline & MPICSR & MPOS & MTRUST \\
\hline MPOS & .001 & & \\
\hline MTRUST & & .001 & \\
\hline MOCB & .001 & & .001 \\
\hline
\end{tabular}




\section{Discussion of Results}

Although the CSR has achieved the attention of industry, academia, and research in recent years, the micro aspect of CSR is still explored less. To address this gap, the study has offered a model of path analysis through direct and sequential indirect effects that link perceived internal CSR to perceived organizational support, trust, and organizational citizenship behavior. The entire hypothesizes received the support of data. When employees perceive that their management either directly through supervisor or through the transparent role of the HR department cares for them, they reciprocate a positive attitude and feel pride at work. Similarly, providing a caring, safe, and friendly work environment develops a sense of perceived support of the organization among the employees so they are likely to stay at the job, thereby study confirms H1.

Perceived organizational support is the feeling of organizational care for employees and trust is an outcome of perceived organizational support; therefore, organizations cannot ignore the trust of employees. Trust is indispensable for creating a healthy environment in the organization (Bruhn, 2001). The organizations' ethical treatment for employees can affect the relationship between them in terms of sense of security, belongingness, self-esteem, and purpose for work for employees (Bauman \& Skitka, 2012) that is consistent with $\mathrm{H} 2$.

Employees' trust in an organization develops positive behavior among employees and plays a significant role in maintaining the long-term success of the organization (Mey Werner, \& Theron, 2014). Getting fair treatment from an organization impacts the behavior of employees. The intriguing findings of the studies of Dirks and Ferrin, (2002) and Mey et al. (2014) show a positive relationship between trust and OCB. Therefore, $\mathrm{H} 3$ is found consistent with the literature observed.

According to the study of Folger, Cropanzano, and Goldman, (2005), the employees gauge the performance of organization based on ethical treatment. When an organization shows care and interest in employees' needs and wants, the employees develop benevolent attitudes and a positive relationship with the organization (Organ, 1988). When employees find that their organization involved in ethical behaviors, they also start feeling positively, which more likely results as increased OCB (Hansen, et al., 2011). Therefore, $\mathrm{H}_{4}$ is confirmed. Similarly, $\mathrm{H}_{5}$ is also supported by data and is confirmed.

\subsection{Theoretical Implications}

Internal CSR is an 'internal marketing' tool that help in retaining the employees and develop their positive perceptions for the organization (Low, 2016). Employees' 
positive perceptions of internal CSR further enhances their perception of organizational support, which leads to trust. As a result, they reciprocate this attitude as positive behavior (Rhodas \& Eisenberger, 2002) like organizational citizenship behavior. Most specifically, this study reveals that perceived internal CSR directly and indirectly impacts organizational citizenship behavior.

The relationships explored in this study are unique in nature. Though some relations have been explored in the west, the impact of employee perception through the linkage of sequential mediation of perceived organizational support and trust with organizational citizenship behavior is one-of-a-kind in Pakistan as per the knowledge of the authors of the study. The perceived organizational support and trust is blended for the first time as sequential and multiple mediators between perceived internal CSR and organizational citizenship behavior. Surprisingly, both internal CSR and organizational citizenship behavior are discretionary types found to positively reciprocate each other.

Finally, the study has contributed to the gaps identified in CSR literature by Aguilera (2007), Aguinis and Glavas, (2012); De Roeck et al. (2014), Abd-Elmotaleb et al. (2015), Frederick (2016), and Glavas (2016) who suggested exploring the micro CSR in a bit more complex way.

Similarly, from the theoretical point of view, the explored mediation mechanism will be helpful for managers, future researchers, and academicians to understand why and how the relationship between perceived internal CSR and organizational citizenship behavior subsists. The level of HR practices as internal CSR allows employees to perceive the organizational support and respect the organization. Thus, the results of the study suggest that practicing internal CSR can engender the positive attitude and behavior among employees for the management.

\subsection{Managerial Implications}

The present study provides the important managerial implications that suggests that the organizations investing on employees through internal CSR can keep long lasting relationships with stakeholders through trust. The results of the study advocate that organizations interested in cultivating citizenship behavior among employees may find directions through the present literature of study. Internal CSR are employee-centered practices that contribute to employee perception for organizational support and organizational trust for their positive behavior. The employees perceiving positive behavior of the organization through internal CSR show less tendency of switching their jobs because they reciprocate the behavior under social exchange. Furthermore, the internal CSR can be used as tool to improve the efficiency of the HR department. 
Similarly, the HR department may provide better training, safety, involvement in organizational communication, etc. as organizational support for building employee trust. Finally, internal CSR should be individualized and personal as individuals are unique and they need unique treatment as well.

\section{Conclusion, Limitations, and Future Recommendations}

Besides several theatrical and managerial implications, several limitations exist in the study. The present study deficits in the qualitative part of research that could provide further the depth of results through interviews of employees that the quantitative study does not reveal. The study can be explored through a longitudinal framework. This study has focused on the telecom industry in Pakistan where the CSR practices are commonly applied. However, the same framework can be applied on other service industries like banking, hospitality, health sectors, and other industries to enhance the generalizability of finding. The present study has explored the employees as stakeholders, while future studies can explore the franchisors as internal stakeholders for internal CSR.

Similarly, internal and external CSR perception can be observed in one model together to see their effect on stakeholders' behaviors. Further, the internal CSR of different organizations and industries can be compared as well. Though like every study the present study also has some limitations, the present study has explored the worthy consideration for the telecom industry. Further, the study can be applied on other industries and employees like part-time and temporary employees, etc. to better understand the internal CSR practices. Finally, the findings show that the implementation of internal CSR has great positive effects on employees' discretionary behaviors as organizational citizenship behaviors. Therefore, it is a necessity for management of organizations to champion internal CSR by contributing improved HR practices.

\section{References}

Abd-Elmotaleb, M., Saha, S. K., \& Hamoudahb, A. E. M. (2015). Rethinking the employees' perceptions of corporate social responsibility. International Business Research, 8(3), 121-132.

Aguilera, R. V., Rupp, D. E., Williams, C. A., \& Ganapathi, J. (2007). Putting the S back in corporate social responsibility: A multilevel theory of social change in organizations. Academy of management review, 32(3), 836-863.

Aguinis, H., \& Glavas, A. (2012). What we know and don't know about corporate social responsibility a review and research agenda. Journal of management, 38(4), 932-968.

Ali, I., Rehman, K. U., Yilmaz, A. K., Nazir, S., \& Ali, J. F. (2010). Effects of corporate social responsibility on consumer retention in the cellular industry of Pakistan. African Journal of Business Management, 
4(4), 475-485.

Allen, D. G., Peltokorpi, V., \& Rubenstein, A. L. (2016). When “embedded” means "stuck”: Moderating effects of job embeddedness in adverse work environments. Journal of Applied Psychology, 101(12), $1670-1686$.

Altuntas, S., \& Baykal, U. (2010). Relationship between nurses' organizational trust levels and their organizational citizenship behaviors. Journal of Nursing Scholarship, 42(2), 186-194.

Aryee, S., Budhwar, P. S., \& Chen, Z. X. (2002). Trust as a mediator of the relationship between organizational justice and work outcomes: Test of a social exchange model. Journal of organizational Behavior, 23(3), 267-285.

Azim, M. T., Diyab, A. A., \& Al-Sabaan, S. A. (2014). CSR, employee job attitude and behavior: Saudi bank experience. Transylvanian Review of Administrative Sciences, 10(43), 25-47.

Bauman, C. W., \& Skitka, L. J. (2012). Corporate social responsibility as a source of employee satisfaction. Research in Organizational Behavior, 32, 63-86.

Beheshtifar, M., \& Herat, B. H. (2013). To promote employees' commitment via perceived organizational support. International Journal of Academic Research in Business and Social Sciences, 3(1), 306-313.

Brammer, S., Millington, A., \& Rayton, B. (2007). The contribution of corporate social responsibility to organizational commitment. The International Journal of Human Resource Management, 18(10), 1701-1719.

Blau, P. (1964). Power and exchange in social life. New York: John Wiley \& Sons.

Brown, S., Gray, D., McHardy, J., \& Taylor, K. (2015). Employee trust and workplace performance. Journal of Economic Behavior $\mathcal{E}$ Organization, 116, 361-378.

Bruhn, J. G. (2001). Trust and the health of organizations. New York: Kluwer.

Cable, D. M., \& Judge, T. A. (1996). Person-organization fit, job choice decisions, and organizational entry. Organizational Behavior and Human Decisions Processes, 67(3), 294-311.

Chen, Z., Eisenberger, R., Johnson, K. M., Sucharski, I. L., \& Aselage, J. (2009). Perceived organizational support and extra-role performance: which leads to which? The Journal of social psychology, 149(1), 119-124.

Chung, Y. W. (2015). The role of person-organization fit and perceived organizational support in the relationship between workplace ostracism and behavioral outcomes. Australian Journal of Management, 42(2), 1-22.

Cropanzano, R., \& Mitchell, M. S. (2005). Social exchange theory: An interdisciplinary review. Journal of management, 31(6), 874-900.

Dahlsrud, A. (2008). How corporate social responsibility is defined: an analysis of 37 definitions. Cor- 
porate social responsibility and environmental management, 15(1), 1-3.

De Roeck, K., Marique, G., Stinglhamber, F., \& Swaen, V. (2014). Understanding employees' responses to corporate social responsibility: mediating roles of overall justice and organizational identification. The International Journal of Human Resource Management, 25(1), 91-112.

Dirks, K. T., \& Ferrin, D. L. (2002). Trust in leadership: Meta-analytic findings and implications for research and practice. Journal of applied psychology, 87(4), 611-628.

Doda, S. (2015). The importance of corporate social responsibility. Journal of Sociological Research, 6(1), 86-91.

Eisenberger, R., Huntington, R., Hutchinson, S., \& Sowa, D. (1986). Perceived organizational support. Journal of Applied Psychology, 77, 500-507.

Eisenberger, R., Aselage, J., Sucharski, I. L., \& Jones, J. R. (2004). Perceived organizational support. In J. A. M. Coyle-Shapiro, L. M. Shore, M.S. Taylor, \& L. E. Tetrick (Eds.), The employment relationship: Psychological and contextual perspectives. (pp. 206-225). Oxford, UK: Oxford University Press.

European Commission (2001). Promoting a European framework for corporate social responsibility. Available at: Europa.eu/rapid/press-release_DOC-01-9_en.pdf

Ferreira, P., \& Real de Oliveira, E. (2014). Does corporate social responsibility impact on employee engagement? Journal of Workplace Learning, 26(3/4), 232-247.

Folger, R., Cropanzano, R., \& Goldman, B. (2005). What is the relationship between justice and morality. In J. Greenberg \& J. A. Colquitt (Eds.), Handbook of organizational justice (pp. 215-245). Mahwah, NJ: Erlbaum.

Fornell, C., \& Larcker, D. F. (1981). Evaluating structural equation models with unobservable variables and measurement error. Journal of marketing research, 18(1) 39-50.

Glavas, A. (2016). Corporate social responsibility and organizational psychology: An integrative review. Frontiers in psychology, 7, 1-13.

Glavas, A., \& Kelley, K. (2014). The effects of perceived corporate social responsibility on employee attitudes. Business Ethics Quarterly, 24(02), 165- 202.

Goergen, M., Chahine, S., Brewster, C., \& Wood, G. (2013). Trust, owner rights, employee rights and firm performance. Journal of Business Finance $\mathcal{E}$ Accounting, 40(5-6), 589-619.

Gond, J. P, El-Akremi, A., Igalens, J., \& Swaen, V. (2010). The human resources contribution to responsible leadership: An exploration of the CSR-HR interface. Journal of Business Ethics, 98(1), 115- 132.

Güçer, E., \& Demirdağ, Ş. A. (2014). Organizational trust and job satisfaction: A Study on hotels. Business Management Dynamics, 4(1), 12-28. 
Gunzler, D., Chen, T., Wu, P., \& Zhang, H. (2013). Introduction to mediation analysis with structural equation modeling. Shanghai Archives of Psychiatry, 25(6), 390-394.

Hair, J. F., Black, W. C., Babin, B. J., \& Anderson, R. E. (2010). Multivariate data analysis: A global perspective. Upper Saddle River, NJ.: Pearson.

Hansen, S. D., Dunford, B. B., Boss, A. D., Boss, R. W., \& Angermeier, I. (2011). Corporate social responsibility and the benefits of employee trust: A cross-disciplinary perspective. Journal of Business Ethics, 102(1), 29-45.

Hameed, I., Riaz, Z., Arain, G. A., \& Farooq, O. (2016). How do internal and external CSR affect employees' organizational identification? A perspective from the group engagement model. Frontiers in Psychology, 7, 1-13.

Hofman, P. S., \& Newman, A. (2014). The impact of perceived corporate social responsibility on organizational commitment and the moderating role of collectivism and masculinity: evidence from China. The International Journal of Human Resource Management, 25(5), 631-652.

Iacobucci, D., Saldanha, N., \& Deng, X. (2007). A meditation on mediation: Evidence that structural equations models perform better than regressions. Journal of Consumer Psychology, 17(2), 139-153.

Ismail, T. N. T. (2011). Corporate social responsibility: The influence of the silver book. International Journal of Business and Management Studies, 3(2), 371-383.

Johnson, B., \& Christensen, L. (2004). Educational research: Quantitative, qualitative, and mixed approaches (2 $2^{\text {nd }}$ Edition). Boston, MA: Pearson Education.

Jones, D. A., Willness, C. R., \& Madey, S. (2014). Why are job seekers attracted by corporate social performance? Experimental and field tests of three signal-based mechanisms. Academy of Management Journal, 57(2), 383-404.

Katz, D. (1964). The motivational basis of organizational behavior. Behavioral Science, 9(2), 131- 146.

Kim, H. R., Lee, M., Lee, H. T., \& Kim, N. M. (2010). Corporate social responsibility and employeecompany identification. Journal of Business Ethics, 95(4), 557- 569.

Kim, K. Y., Eisenberger, R., \& Baik, K. (2016). Perceived organizational support and affective organizational commitment: Moderating influence of perceived organizational competence. Journal of Organizational Behavior, 37(4), 558-583.

Kolk, A., Vock, M., \& Dolen, W. (2016). Micro foundations of partnerships: Exploring the role of employees in trickle effects. Journal of Business Ethics, 135(1), 19-34.

Konijnenburg, L. (2010). The effect of perceived supervisor support and perceived organizational support on employees' resistance to change. School of Business and Economics.

KPMG. 2013. The KPMG survey of corporate responsibility reporting 2013. Available at: http://www.kpmg. com/Global/en/IssuesAndInsights/ArticlesPublications/corporate-responsibility/Documents/ 
corporate-responsibility-reporting-survey-2013-v2.pdf

Krishnan, J., \& Mary, V. S. (2012). Perceived organizational support-an overview on its antecedents and consequences. International Journal of Multidisciplinary Research, 2(4), 1-13.

Lee, C. K., Song, H. J., Lee, H. M., Lee, S., \& Bernhard, B. J. (2013). The impact of CSR on casino employees' organizational trust, job satisfaction, and customer orientation: An empirical examination of responsible gambling strategies. International Journal of Hospitality Management, 33, 46-415.

Low, M. P. (2016). Corporate Social Responsibility and the evolution of internal corporate social responsibility. Asian Journal of Social Sciences and Management Studies 3(1), 56-74.

Meeker, W. Q., Escobar, L. A., \& Lu, C. J. (1998). Accelerated degradation tests: Modeling and analysis. Technometrics, 40(2), 89-99.

Mey, M., Werner, A, \& Theron, A. (2014). The influence of perceptions of organizational trust and fairness on employee citizenship. Problems and Perspectives in Management, 12(3), 99- 105.

Mory, L., Wirtz, B. W., \& Göttel, V. (2016). Factors of internal corporate social responsibility and the effect on organizational commitment. The International Journal of Human Resource Management, 27(13), 1393-1425.

Newman, A., Nielsen, I., \& Miao, Q. (2015). The impact of employee perceptions of organizational corporate social responsibility practices on job performance and organizational citizenship behavior: Evidence from the Chinese private sector. The International Journal of Human Resource Management, 26(9), 1226- 1242.

Nunnally, J. C., \& Bernstein, I. H. (1994). The assessment of reliability. Psychometric Theory, 3(1), 248- 292.

Organ, D. W. (1988). Organizational citizenship behavior: The good soldier syndrome. Lexington Books/DC Heath and Com.

Parker, C. P., Baltes, B. B., Young, S. A., Huff, J. W., Altmann, R. A., Lacost, H. A., \& Roberts, J. E. (2003). Relationships between psychological climate perceptions and work outcomes: A metalanalytic review. Journal of Organizational Behavior, 24(4), 389-416.

Podsakoff, N. P., Whiting, S. W., Podsakoff, P. M., \& Blume, B. D. (2009). Individual- and organizational-level consequences of organizational citizenship behaviors: A meta- analysis. Journal of Applied Psychology, 94(1), 122- 141.

Podsakoff, P. M., MacKenzie, S. B. Morrman, R. H. \& Fetter, R. (1990) Transformational leader behaviors and their effects on follower's trust in leader satisfaction and organizational citizenship behaviors. Leadership Quarterly, 1(2), 107-142.

Prutina, Ž., \& Šehić, D. (2016). Employees' perceptions of corporate social responsibility: a case study of award recipient. Ekonomskamisaoipraksa, 3(1), 239-260.

Rhoades, L., \& Eisenberger, R. (2002). Perceived organizational support: A review of the literature. Journal 
of Applied Psychology, 87(4), 698-714.

Robinson, S. L. (1996). Trust and breach of the psychological contract. Administrative Science Quarterly, 41(4), 574- 599.

Rupp, D. E., \& Mallory, D. B. (2015). Corporate social responsibility: Psychological, person-centric, and progressing. The Annual Review of Organizational Psychology and Organizational Behavior, 2(1), 2011-236.

Rupp D. E., Shao R., Thornton M. A., \& Skarlicki, D. P. (2013). Applicants' and employees' reactions to corporate social responsibility: The moderating effects of first-party justice perceptions and moral identity. Personal Psychology, 66(4), 895-933.

Rupp, D. E., Ganapathi, J., Aguilera, R. V., \& Williams, C. A. (2006). Employee reactions to corporate social responsibility: An organizational justice framework. Journal of Organizational Behavior, 27(4), $537-543$.

Rusu, R., \& Baboş, A. (2015). Organizational trust between institutional and interpersonal trust. Scientific Bulletin, 20(2), 55-60.

Shaffer, J. P. (1995). Multiple hypothesis testing. Annual Review of Psychology, 46(1), 561-584.

Sheel, R. C., \& Vohra, N. (2016). Relationship between perceptions of corporate social responsibility and organizational cynicism: The role of employee volunteering. The International Journal of Human Resource Management, 27(13), 1373-1392.

Shen, J., \& Benson, J. (2016). When CSR is a social norm how socially responsible human resource management affects employee work behavior. Journal of Management, 42(6), 1723-1746.

Shin, I., Hur, W. M., \& Kang, S. (2016). Employees' perceptions of corporate social responsibility and job performance: A sequential mediation model. Sustainability, 8(5), 1-12.

Shore, L.M., E $\mathcal{E}$ Wayne S.J. (1993). Commitment and employee behavior: Comparison of affective commitment and continuance commitment with perceived organizational support. Journal of Applied Psychology, 78, 774-780.

Singh, U., \& Srivastava, K. B. (2016). Organizational trust and organizational citizenship behaviour. Global Business Review, 17(3), 594-609.

Simsarian Webber, S., Bishop, K., \& O’Neill, R. (2012). Trust repair: The impact of perceived organizational support and issue-selling. Journal of Management Development, 31(7), 724-737.

Smith, C. A., Organ, D. W., \& Near, J. P. (1983). Organizational citizenship behavior: Its nature and antecedents. Journal of applied psychology, 68(4), 653-663.

Turker, D. (2009) How corporate social responsibility influences organizational commitment. Journal of Business Ethics, 89(2), 189-204.

Vardaman, J. M., Allen, D. G., Otondo, R. F., Hancock, J. I., Shore, L. M., \& Rogers, B. L. (2016). So- 
cial comparisons and organizational support: Implications for commitment and retention. Human relations, 69(7), 1483-1505.

Valentine, S., \& Barnett, T. (2003). Ethics code awareness, perceived ethical values, and organizational commitment. Journal of personal selling $\mathcal{E}$ Sales Management, 23(4), 359-367.

Vanhala, M., Heilmann, P., \& Salminen, H. (2016). Organizational trust dimensions as antecedents of organizational commitment. Knowledge and Process Management, 23(1), 46-61.

Ward, H., \& Smith, N. C. (2015). Corporate social responsibility at a crossroads: Futures for CSR in the UK to 2015. International Institute for Environment and Development.

Wayne, S. J., Shore, L. M., \& Liden, R. C. (1997). Perceived organizational support and leader-member exchange: A social exchange perspective. Academy of Management Journal, 40(1), 82-111.

Wech, B. A. (2002). Trust context: Effect on organizational citizenship behavior, supervisory fairness, and job satisfaction beyond the influence of leader-member exchange. Business $\mathcal{E}$ Society, 41(3), 353-360.

Wong, Y. T., Wong, C. S., \& Ngo, H. Y. (2012). The effects of trust in organization and perceived organizational support on organizational citizenship behavior: A test of three competing models. The International Journal of Human Resource Management, 23(2), 278-293.

Xu, A. J., Loi, R., \& Ngo, H. Y. (2016). Ethical leadership behavior and employee justice perceptions: The mediating role of trust in organization. Journal of Business Ethics, 134(3), 493-504.

Yildiz, M. L., \& Öncer, A. Z. (2012). Narcissism as a moderator of the relationship between organizational trust and organizational citizenship behavior. International Journal of Business and Social Science, 3(21), 212-222. 